\title{
Effect of algae on flocculation of suspended bed sediments in a large shallow lake. Consequences for ecology and sediment transport processes
}

\author{
Miguel Angel de Lucas Pardo ${ }^{1,2}$ - Dirk Sarpe ${ }^{3}$ - Johan Christian Winterwerp ${ }^{1,2}$
}

Received: 15 July 2014 / Accepted: 17 April 2015 / Published online: 10 May 2015

(C) Springer-Verlag Berlin Heidelberg 2015

\begin{abstract}
Lake Markermeer, a large shallow lake in The Netherlands, suffers from turbidity and ecology problems. As part of a study aiming to mitigate these problems, we study flocculation processes in the lake; in particular, the possible mutual flocculation between algae and re-suspended bed sediments. We show that sediment re-suspended from the bed of the lake can flocculate, forming flocs for which size is a function of the turbulence level in the water column. Moreover, we also demonstrate that algae and re-suspended bed sediments can mutually flocculate, yielding organicinorganic aggregates. These aggregates have different features to those of their individual components, some of which have been measured and characterized in this paper. Furthermore, the characteristics of the resulting organic-inorganic flocs are strongly influenced by the type of algae in the aggregate. We found that, in the case of flocs consisting of bed sediments and filamentous algae, flocculation yields smaller flocs than for bed sediments only, resulting in an increased turbidity in the water column. In the case of flocs consisting of bed sediments and colonial algae, flocs grow faster and become larger than
\end{abstract}

Responsible Editor: Jeremy Spearman

This article is part of the Topical Collection on the 12th International Conference on Cohesive Sediment Transport in Gainesville, Florida, USA, 21-24 October 2013

Miguel Angel de Lucas Pardo

miguel.delucaspardo@deltares.nl

1 Environmental Fluid Mechanics, Delft University of Technology, 2628CN Delft, The Netherlands

2 Marine and Coastal Management, Deltares, 2629HD Delft, The Netherlands

3 Netherlands Institute of Ecology (NIOO), 3631 AC Nieuwersluis, The Netherlands bed sediment flocs, which may result in the depletion of most colonies from the water column.

Keywords Flocculation · Cohesive sediments · Blue-green algae $\cdot$ Markermeer $\cdot$ Turbidity

\section{Introduction}

The Markermeer is a large, man-made freshwater lake located in the centre of The Netherlands. Together with the northern IJsselmeer, it is the largest freshwater reservoir in Europe. This area is known as the IJsselmeer Region. During the last decades, the lake has experienced a decrease in its ecological values (Noordhuis and Houwing 2003; Van Eerden and van Rijn 2003). This ecological decline has been attributed to high turbidity levels and sediment transport rates in the lake (van Duin 1992; Van Kessel et al. 2008). In this paper, we study the flocculation of suspended bed sediments in the Markermeer. Flocculation affects the size and settling velocity of suspended sediments. The rate at which suspended sediments flocculate is a function of sediment concentration, hydrodynamics and the presence of biota in the water column, amongst others (Mietta et al. 2009a; Winterwerp 1998). Moreover, floc sizes do have an impact not only on settling fluxes to the bed but also on light climate in the water column. Hence, the importance of studying flocculation processes in the Markermeer.

Figure 1 shows a schematic illustration of the sediment layers in the bed of the lake. The uppermost layer is a thin oxic sediment layer, highly bioturbated and, due to its low erosion threshold, frequently re-suspended (de Lucas Pardo et al. 2013). Below, a thicker and stronger anoxic layer can be found, which is eroded only during storm events (de Lucas Pardo et al. 2013; Vijverberg et al. 2011). Finally, the bottom layer consists of old deposits from the period in which the 
Fig. 1 Schematic illustration of the sediment layers in the bed of Markermeer

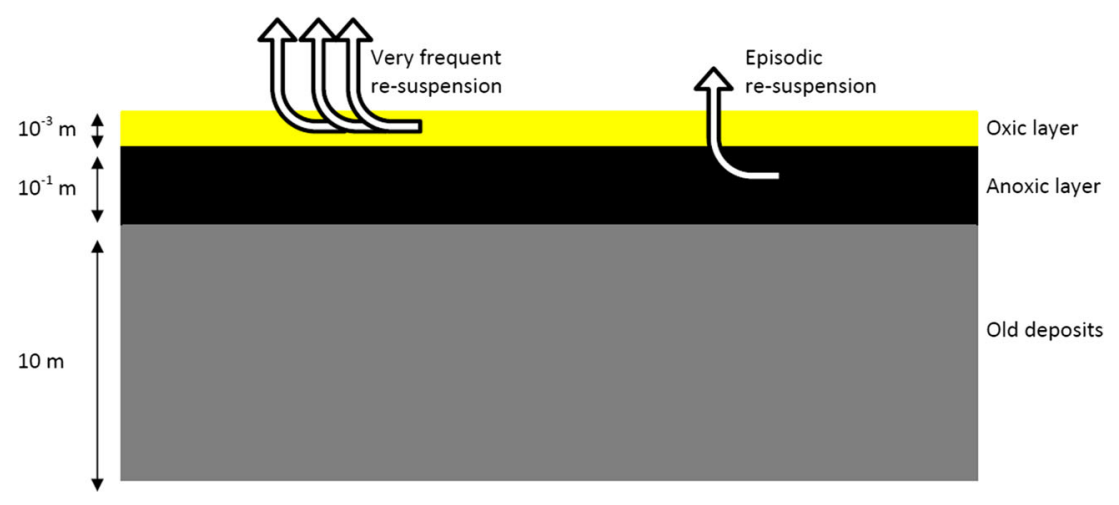

whole region was still an estuary. Because of the frequent resuspension of the oxic layer, we chose sediments from this layer as the main material for our flocculation study. Nevertheless, the flocculation behaviour of sediment form the anoxic layer is addressed as well.

The work described in this manuscript follows on a number of hypotheses on the relevance of flocculation in the Markermeer. The first hypothesis is that suspended sediments, mobilized from the bed, can flocculate and attain an equilibrium floc size which is a function of the turbulence level. The first hypothesis is tested through small-scale flocculation experiments in mixing jars. The evolution of the floc size distribution (FSD) is monitored, as well as the obscuration caused by the sediment suspension. The obscuration is defined as the percentage of either absorbed or scattered light from the laser beam in the particle sizer. Thus, obscuration is a measure of the turbidity induced by the suspension. However, obscuration cannot be translated directly into NTU, Secchi depth or any other known light climate parameter. An increase in obscuration can be expected because of an increase in the number of fines or an increase in the overall concentration, whereas a decrease in obscuration can be expected upon aggregation of flocs or after settling of sediments to the bottom of the jar. Moreover, different floc structures are likely to diffract and absorb light in different ways and therefore exhibit different obscuration values. The research goal of this small-scale experiment is to characterize the equilibrium floc size for a number of turbulence fields, which are defined by their turbulent shear rate $G$. Similar work was undertaken by Manning et al. (2010) but for a mixture of sand and fines. Moreover, another goal is to find the relationship between obscuration and FSD for suspended bed sediments.

Various studies suggest that variations in turbidity levels in the Markermeer over the years cannot be fully explained by the occurrence of storms and associated re-suspension events. Moreover, the species of algae in the lake have changed over the last decades, attaining overall chlorophyll concentrations that vary over the year in a way that is not understood. These two observations may be related to the mutual flocculation of algae and suspended sediments. Therefore, the second hypothesis is that algae and suspended sediments can flocculate, affecting the floc properties and light climate in the water column. Flocculation between minerals (cohesive sediments) and algae has indeed been reported (Verspagen et al. 2006). Furthermore, previous research has confirmed the existence of large floc aggregates during algae bloom season (Lunau et al. 2006; Mikkelsen 2002; van der Lee 2000b). Moreover, seasonal changes in the settling velocity of fines have been reported (Sanford et al. 2001), which was attributed to seasonal variations in algae (Mikkelsen 2002). Therefore, an effect of algae on floc size and structure is suggested. Further to these observations, Verney et al. (2009) presented a detailed study quantifying the influence of algal blooms on the growth rate of flocs under the influence of a specific turbulence level. In this manuscript, we address the effect of flocculation between algae and sediments on several floc properties and light climates, for a range of turbulence levels, and for two specific species of (blue-green) algae. The role of algae is studied by repeating the experiments for a mixture of bed sediments and algae. Comparison with the results from the bed sediment experiment provides information on the effect of algae. Two species of algae are studied: a species of colonial algae and a species of filamentous algae. In all experiments, filtered Markermeer water is used, free of sediments and algae.

Finally, our third hypothesis is that the characteristics of the resulting organic-inorganic flocs depend on the type of algae added to the suspension. The polysaccharides excreted by both species are expected to enhance flocculation with the suspended sediments. However, we do not study if these algae produce different polysaccharides, affecting flocculation in a different way. Nevertheless, the differences in morphology and characteristics of the algae may also lead to different floc sizes, structure and flocculation behaviour. Mehta et al. (2009) also reported examples of organic-inorganic flocs in a shallow lake.

The structure of this manuscript is as follows. First, the results of the experiments on suspended bed sediments are presented, testing the first hypothesis. Second, the behaviour 
of the algae in the experiments is analysed. This provides relevant information for interpreting the results later presented. Third, the results of the experiments for a mixture of bed sediments and algae are shown, testing hypotheses two and three. A final section is included in which measurements of the flocculation rate with and without algae are presented, to provide further information for the evaluation of hypotheses two and three.

The overall main study aim is to evaluate the relevance of flocculation in the Markermeer, while increasing the present knowledge on the formation of organic-inorganic flocs and its characteristics. In particular, the following research goals are addressed in this manuscript:

- to characterize the equilibrium floc size of Markermeer flocs for a number of turbulence fields.

- to demonstrate the formation of organic-inorganic flocs.

- to prove that the characteristics of the resulting organicinorganic flocs are a function of the type of algae combined in the aggregate, and to quantify the influence of two specific types of algae on these characteristics.

\section{Methods}

\subsection{Mixing jars}

Small-scale flocculation experiments are performed in a JLT6 jar test set-up from VELP Scientifica. The dimensions of the mixing jars are $0.125 \mathrm{~m}$ inner diameter and $0.185 \mathrm{~m}$ height. The turbulence field in the jar is induced by a rotating paddle, placed $0.01 \mathrm{~m}$ above the bottom of the jars. This turbulence field is characterized by its turbulence shear rate $G$. An average value for $G$ in the jar can be approximated with: $\log G=$ $-0.849+1.5 \log \left(60 s_{f}\right)$, where $s_{f}$ is the stirring frequency of the paddle in rotations per second (KIWA 1976). Other methods to estimate $G$ in the jar are available (Bouyer et al. 2005; Nagata 1975). The estimations of $G$ with these methods deviate no more than $5 \%$ from the estimation by KIWA (KIWA 1976) for $G<101 \mathrm{~s}^{-1}$ (Mietta 2010).

\subsection{Experiments}

The following sequence of laboratory experiments is used in the flocculation study. First, a turbulence field of a specific magnitude is applied in a jar containing suspended sediments. Under the influence of turbulence, sediments flocculate and, with time, attain a dynamic equilibrium, characterized by an equilibrium floc size. It is assumed that the equilibrium floc size is reached when there is no further increase in size between three consecutive measurements. The frequency at which these measurements are performed is discussed later in this section. When the equilibrium floc size is attained, the magnitude of the turbulence field is modified, and with time, floc sizes attain a new equilibrium. A complete flocculation experiment consists of six turbulence fields applied to one sediment sample. Figure 2 illustrates the first steps in this sequence. Table 1 shows the sequence of the applied turbulence fields and the initial size of flocs. Before starting an experiment, de-flocculation by ultrasonic treatment is applied to the sediments. The first applied $G$ is always $65 \mathrm{~s}^{-1}$, and thus, the flocs at the beginning of an experiment have the size of the primary particles. When the equilibrium floc size for $G=65 \mathrm{~s}^{-1}$ is reached, $G$ is decreased to $47 \mathrm{~s}^{-1}$. Each sub-experiment is continued until equilibrium. Sediment used for these experiments was sampled from the bed and mixed with Markermeer filtered water.

\subsection{Measuring instrument and measured parameters}

Floc sizes are measured with a Malvern Mastersizer 2000. This is essentially a particle sizer, but it measures some other relevant parameters as well. These are obscuration, volume concentration and specific surface area of particles. Obscuration is defined as the percentage of either absorbed or scattered light from the laser beam
Fig. 2 First steps in the sequence of experiments applied in the current flocculation study

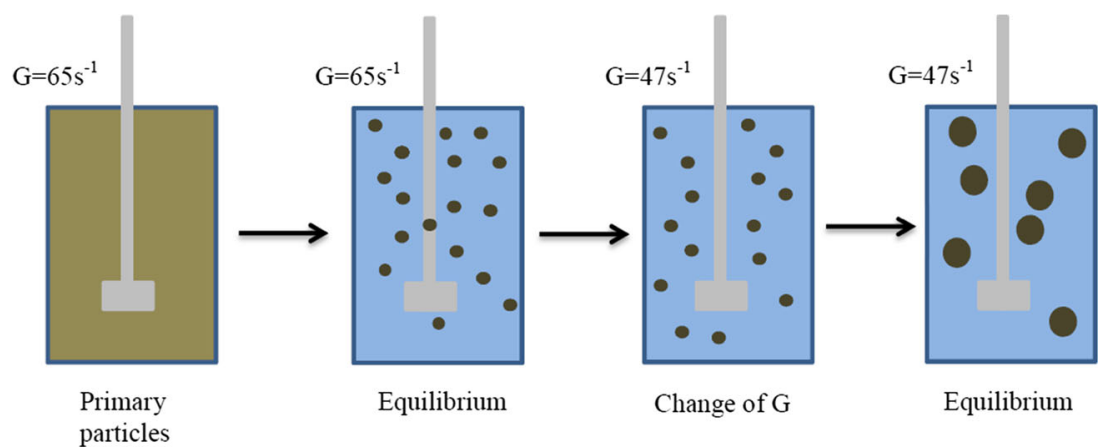


Table $1 G$ characterizing the various turbulence fields, sequence of application and initial floc sizes for each of the sub-experiments

\begin{tabular}{lllllll}
\hline Sequence & $\begin{array}{l}G=65 \mathrm{~s}^{-1} \\
\text { First }\end{array}$ & $\begin{array}{l}G=47 \mathrm{~s}^{-1} \\
\text { Second }\end{array}$ & $\begin{array}{l}G=30 \mathrm{~s}^{-1} \\
\text { Third }\end{array}$ & $\begin{array}{l}G=23 \mathrm{~s}^{-1} \\
\text { Fourth }\end{array}$ & $\begin{array}{l}G=11 \mathrm{~s}^{-1} \\
\text { Fifth }\end{array}$ & $\begin{array}{l}G=6 \mathrm{~s}^{-1} \\
\text { Sixth }\end{array}$ \\
\hline Initial size of flocs & $\begin{array}{c}\text { Primary } \\
\text { particles }\end{array}$ & $\begin{array}{c}\text { Equilibrium floc } \\
\text { size at } G=65 \mathrm{~s}^{-1}\end{array}$ & $\begin{array}{c}\text { Equilibrium floc } \\
\text { size at } G=47 \mathrm{~s}^{-1}\end{array}$ & $\begin{array}{c}\text { Equilibrium floc } \\
\text { size at } G=30 \mathrm{~s}^{-1}\end{array}$ & $\begin{array}{c}\text { Equilibrium floc } \\
\text { size at } G=23 \mathrm{~s}^{-1}\end{array}$ & $\begin{array}{c}\text { Equilibrium floc } \\
\text { size at } G=11 \mathrm{~s}^{-1}\end{array}$ \\
\hline
\end{tabular}

of the particle sizer, which can vary from 0 (clear water) to $100 \%$ (no signal). Given a constant suspended sediment concentration, a decrease in obscuration can be caused by aggregation of flocs. Given a constant size of flocs, a decrease in obscuration can be caused by settling of sediments to the bottom of the jar. Finally, flocs with a different structure may diffract the laser beam in a different way, and therefore, different obscuration for different floc structures can occur. The volume concentration is calculated using Beer-Lambert's law, and the specific surface area is calculated as the total area of particles divided by the total weight. More details on how these parameters are established can be found in the Malvern Mastersizer 2000 user manual (Guide 1998). Literature also provides information on instrument uncertainties and limitations (Berlamont et al. 1993; Sperazza et al. 2004), as well as on comparison between several instruments capable of measuring floc sizes, revealing that Malvern underestimates the size of the flocs with respect to other instruments (pipette and SediGraph for example) (Vdović et al. 2010). Nevertheless, Malvern is still regarded as a valuable instrument, specially recommended for intercomparisons and to track changes in grain sizes (Berlamont et al. 1993). Moreover, there are many examples in literature of studies that have made use of Malvern to measure floc sizes (Bainbridge et al. 2012; Bale and Morris 1987; Dyer and Manning 1999; Lartiges et al. 2001; Lee et al. 2011; McCabe 1991) and primary particles at the

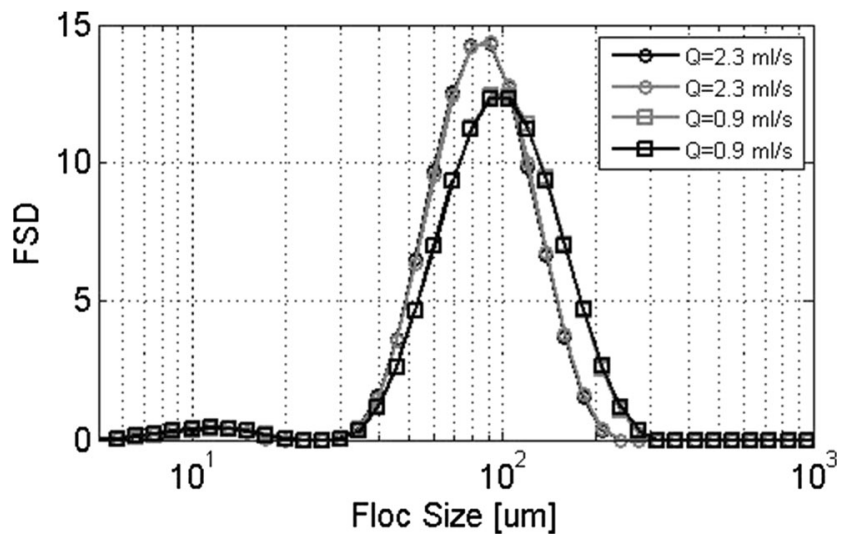

Fig. 3 Floc size distributions (FSD) measured at several discharge rates. Sediments from the anoxic layer at a $0.19 \mathrm{~g} / 1$ concentration. The turbulence shear rate is characterized by $G=47 \mathrm{~s}^{-1}$ laboratory (Lee et al. 2011; Mikkelsen and Pejrup 1998; Mikkelsen and Pejrup 2000).

\subsection{Measurement and sampling parameters}

Suspended sediments are sampled from the mixing jars and pumped to the particle sizer and back into the mixing jars. The pump discharge for sampling should be low enough to avoid break-up of flocs. Mietta (2010) found that a discharge of $1.3 \mathrm{ml} / \mathrm{s}$ would avoid break-up for kaolinite suspensions at a specific $\mathrm{pH}$ and salt concentration. The behaviour of suspended bed sediments from Markermeer at two discharge rates is shown in Fig. 3. It appears that the break-up of flocs is avoided by using a discharge of $0.9 \mathrm{ml} / \mathrm{s}$. Lower discharge would result in the settling of flocs within the sampling tubes. The length of the tubes is $85 \mathrm{~cm}$, which is the minimum length within the current set-up. Lengths up to $120 \mathrm{~cm}$ are possible without affecting the size of sampled flocs (Mietta 2010).

Next, we study whether large flocs break-up as a result of sampling. Figure 4 shows the effect of sampling from an equilibrium sediment suspension at $G=65 \mathrm{~s}^{-1}$. The equilibrium floc size, characterized by $D_{50}=81 \mu \mathrm{m}$, is not affected by sampling. However, this is not the case for the larger flocs. Figure 5 shows how $D_{50}$ decreases as a result of sampling for a sediment suspension at equilibrium at $G=30 \mathrm{~s}^{-1}$. Flocs larger than $100 \mu \mathrm{m}$ break up during sampling due to the stresses in the sampling tubes. This affects the results of subsequent measurements, since the flocs are pumped back into the mixing jar after sampling and measuring. Thus, sampling time must be

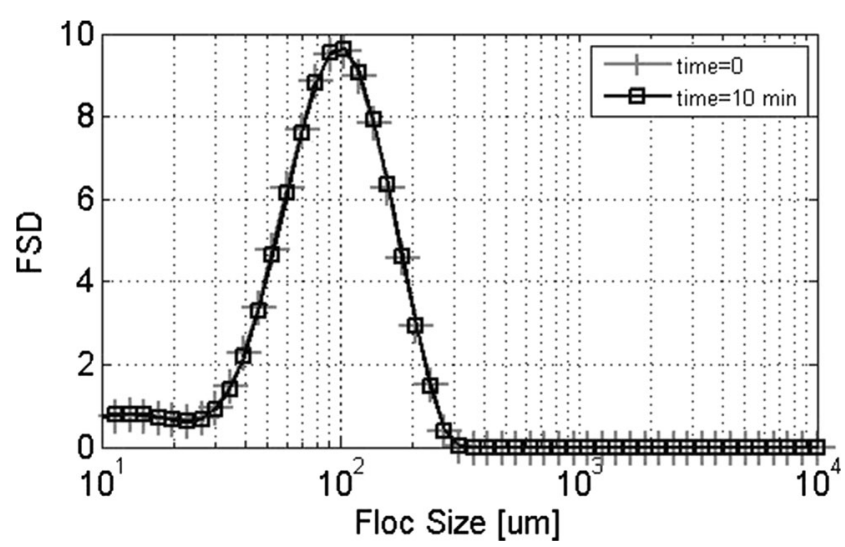

Fig. 4 FSDs for $D_{50}=81 \mu \mathrm{m}$. Sediment concentration is $0.19 \mathrm{~g} / 1$. Interval between measurements is $10 \mathrm{~min}$ 


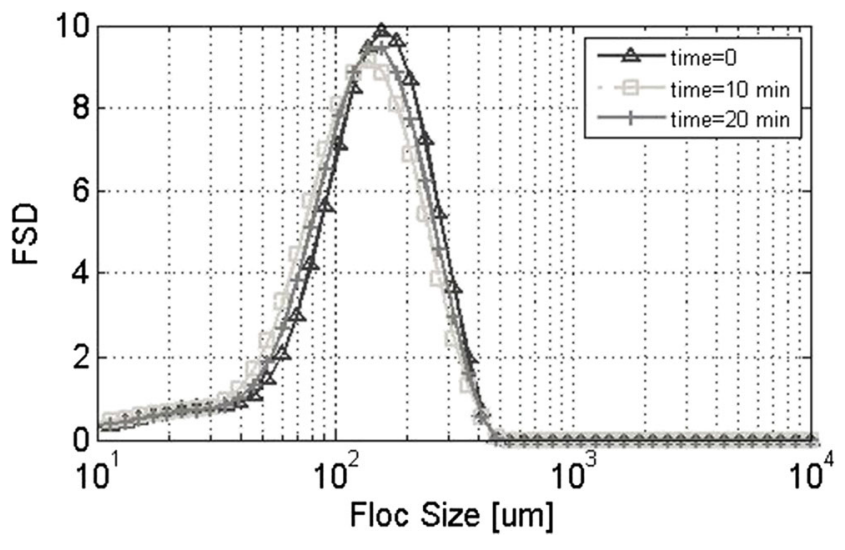

Fig. 5 FSDs measured at 10 min interval. $D_{50}$ decreases from 132 to $114 \mu \mathrm{m}$ as a result of sampling. Sediment concentration is $0.19 \mathrm{~g} / \mathrm{l}$

kept to a minimum, minimizing break-up of flocs. Another measure undertaken to minimize the impact of this break-up is to increase the time between measurements. It is assumed that increasing this period allows for re-flocculation. Figure 6 shows that increasing the time between measurements to $30 \mathrm{~min}$ is enough to mitigate for this break-up. When equilibrium is attained, an extra measurement $1 \mathrm{~h}$ after the detection of the equilibrium is performed as a final check.

\section{5 (Blue-green) algae}

Two species of blue-green algae (or cyanobacteria) were purchased from the Netherlands Institute for Sea Research (NIOZ): Aphanizomenon sp. (CCY9904) and Aphanotece sp. (CCY0618). Upon arrival, the algae were in their exponential growth phase, indicating a good state. The concentration in the culture is measured immediately prior to an experiment, by counting the diatom individuals in a small sample of known volume, using a high resolution microscope. Upon calculation of the concentration in the culture, a certain volume is added to the jars to get the desired algae concentration.

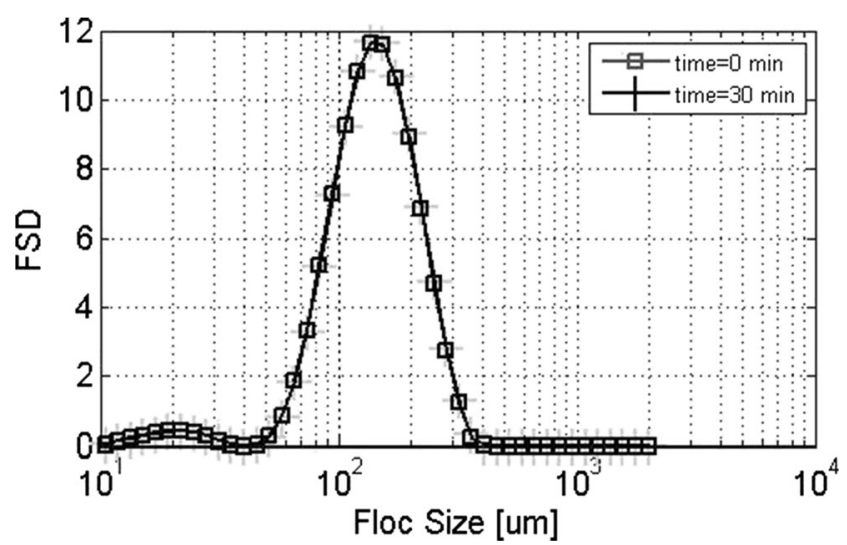

Fig. 6 FSDs measured at $30 \mathrm{~min}$ interval. $D_{50}=131 \mu \mathrm{m}$. Sediment concentration is $0.19 \mathrm{~g} / 1$

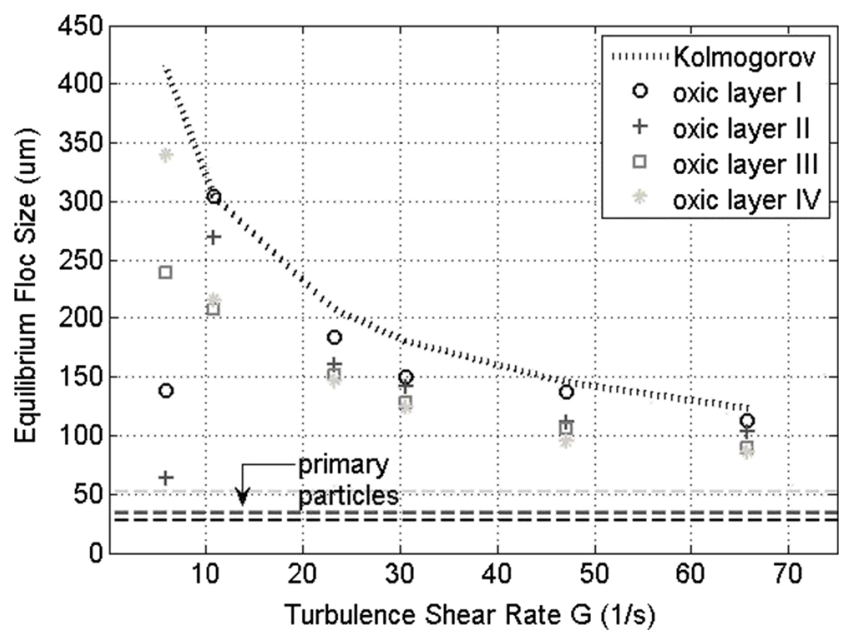

Fig. 7 Equilibrium floc sizes achieved at each of the studied turbulence levels, for sediments from the oxic layer. The sediment concentration is $0.19 \mathrm{~g} / \mathrm{l}$ in all cases

The concentration of algae is measured again after an experiment to check the survival rate of algae. This survival rate was found to always be $100 \%$. Note that the experiment time was maximal $24 \mathrm{~h}$.

\subsection{Microscope images}

Some microscope images are reported in the results section. The samples did not undergo any specific or standardized pretreatment. Flocs were sampled from the jars with a small syringe and placed on a small petri dish. The diameter of the mouth of the syringe was $1 \mathrm{~mm}$, to avoid break-up of flocs upon sampling. The images were taken in regions of the sample where the concentration of flocs was not qualitatively large, so that the light could go through the flocs.

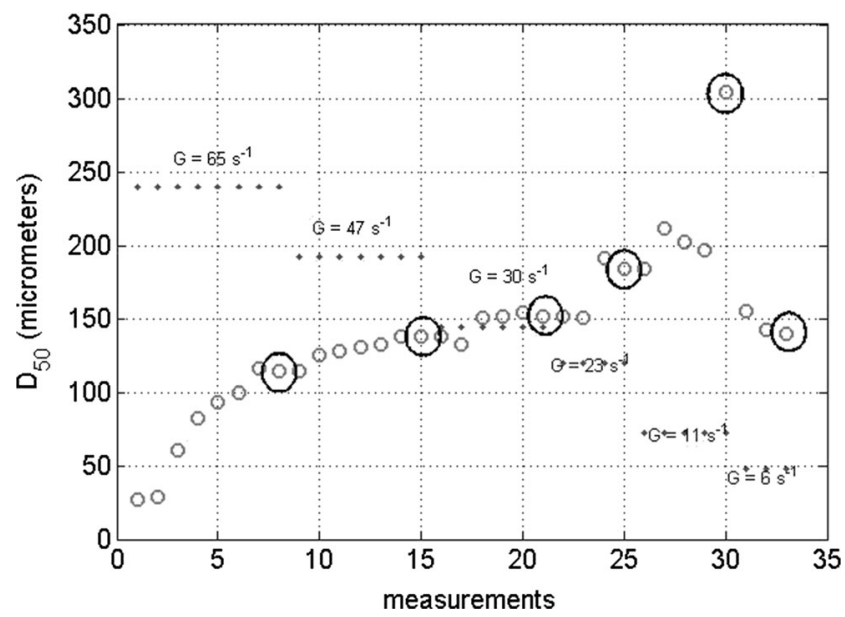

Fig. 8 Evolution of $D_{50}$ of the measured FSD over an experiment, for sediments from the oxic layer I. $G$ is indicated. The horizontal axis depicts the sequence of measurements, reflecting the experiment time. The equilibrium floc size at each $G$ is marked with a black circle 
Table 2 G characterizing each of the turbulence fields, order in which turbulence fields are applied and initial floc sizes for each of the studied turbulence fields

\begin{tabular}{lllllll}
\hline Order & $\begin{array}{l}G=65 \mathrm{~s}^{-1} \\
\text { First }\end{array}$ & $\begin{array}{l}G=47 \mathrm{~s}^{-1} \\
\text { Second }\end{array}$ & $\begin{array}{l}G=30 \mathrm{~s}^{-1} \\
\text { Third }\end{array}$ & $\begin{array}{l}G=23 \mathrm{~s}^{-1} \\
\text { Fourth }\end{array}$ & $\begin{array}{l}G=11 \mathrm{~s}^{-1} \\
\text { Fifth }\end{array}$ & $\begin{array}{l}G=6 \mathrm{~s}^{-1} \\
\text { Sixth }\end{array}$ \\
\hline $\begin{aligned} \text { Initial size } \\
\text { of flocs }\end{aligned}$ & $\begin{array}{c}\text { Primary } \\
\text { particles }\end{array}$ & $\begin{array}{c}\text { Equilibrium floc } \\
\text { size from } G=65 \mathrm{~s}^{-1}\end{array}$ & $\begin{array}{c}\text { Equilibrium floc s } \\
\text { ize from } G=47 \mathrm{~s}^{-1}\end{array}$ & $\begin{array}{c}\text { Equilibrium floc } \\
\text { size from } G=30 \mathrm{~s}^{-1}\end{array}$ & $\begin{array}{c}\text { Equilibrium floc } \\
\text { size from } G=23 \mathrm{~s}^{-1}\end{array}$ & $\begin{array}{c}\text { Equilibrium floc } \\
\text { size from } G=11 \mathrm{~s}^{-1}\end{array}$ \\
\hline
\end{tabular}

\section{Results and discussion}

\subsection{Flocculation of suspended bed sediments. Effect of turbulence}

Figure 7 shows the equilibrium floc sizes obtained at each of the studied turbulence levels and for four samples of sediments from the oxic layer. These samples are all collected from the same place in the lake and are labelled as I, II, III and IV. In all cases, the sediment concentration in the jar is $0.19 \mathrm{~g} / \mathrm{l}$. The floc sizes plotted in Fig. 7 are characterized by the median particle diameter $D_{50}$ of the measured size distribution, whereas the turbulence levels are characterized by the turbulent shear rate, $G$. The Kolmogorov micro-scale and the size of the primary particles are plotted for reference. Figure 8 shows, as an example, the evolution of $D_{50}$ over a flocculation experiment for sediments from oxic layer I. The equilibrium floc sizes attained at each $G$ are marked with a black circle. These equilibrium sizes are the values plotted in Fig. 7 for oxic layer I. Finally, Table 2 shows the $G$ of each of the studied turbulence fields, and the sequence in which the turbulence fields are applied and the initial size of flocs.

Below the size of the Kolmogorov micro-scale, viscosity begins to have a noticeable effect on the motion of the fluid. At length scales beyond the Kolmogorov micro-scale,

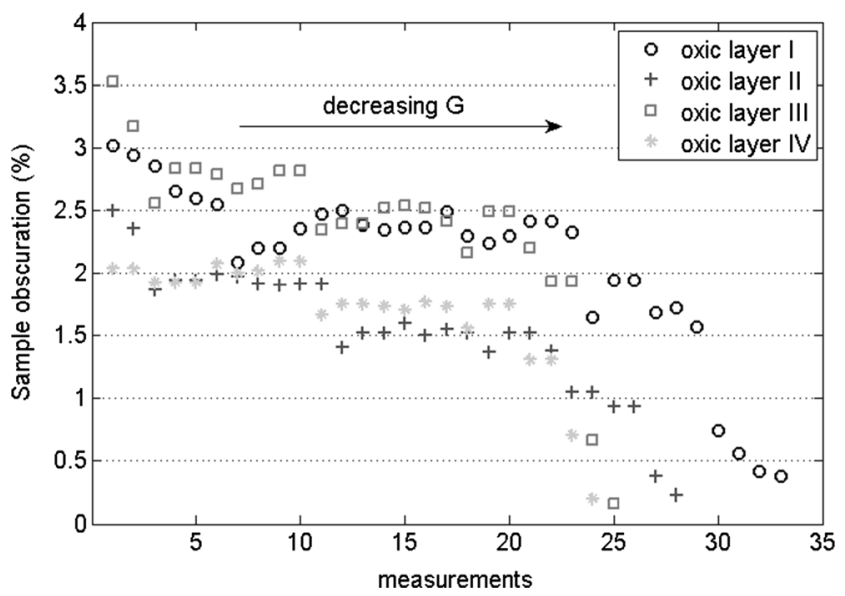

Fig. 9 Measured obscuration for sediments from the oxic layer. The first measurements correspond to the largest turbulence shear rate, whereas the last measurements correspond to the smallest turbulence shear rate, with all the intermediate turbulence levels in between turbulent shear stresses become rapidly larger than the yield stresses of flocs, resulting in floc break-up. Therefore, flocs can attain equilibrium sizes of about the Kolmogorov microscale (Fettweis et al. 2006; Mietta et al. 2009a; Winterwerp 1998). In fact, Fig. 7 shows that all samples follow the Kolmogorov micro-scale until somewhere between $G=6$ and $G=$ $11 \mathrm{~s}^{-1}$, when settling occurs. This settling becomes apparent through a 55 to $95 \%$ decrease in the measured volume concentration, as well as a 300 to $900 \%$ increase in the specific surface of particles (e.g. only the smallest particles remain in suspension). In oxic layer III and oxic layer IV, the particles remaining in suspension continue flocculating until an equilibrium floc size of 245 and $340 \mu \mathrm{m}$, respectively; whereas for the other two samples, flocculation did not occur anymore at this lower turbulence rate. This difference in behaviour is explained; because for oxic layer III and IV, the volume concentration after settling is 0.08 and $0.1 \%$, respectively; while for oxic layer II and oxic layer III, this concentration is 0.01 and $0.02 \%$ only, respectively. Flocculation cannot occur (fast enough) at these very low concentrations.

Figure 9 shows the obscuration registered for each of the measurements on the oxic layer sediments. The first measurements were carried out at the largest turbulent shear rate, while the last measurements were undertaken at the smallest turbulent shear rate, with intermediate turbulence levels in between. The latter becomes apparent in Fig. 10, where an indication of

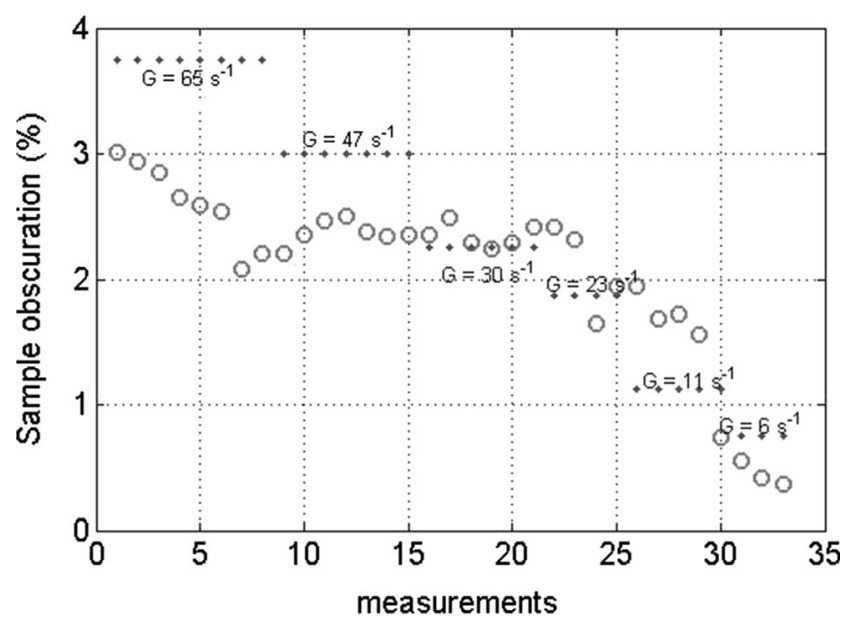

Fig. 10 Measured obscuration for sediments from the oxic layer I. $G$ is indicated for clarification of Fig. 9 
$G$ at every measurement at the oxic layer I experiment is given for clarification. Overall, obscuration decreases as floc size increases, ranging from 3.5 to $0.15 \%$ and suggesting a decrease in small particle concentration. The lowest obscuration values are measured after settling. With all flocs in suspension, the lowest obscuration values are around $1 \%$.

Figure 11 shows the equilibrium floc sizes at each of the turbulence levels for two samples of sediments from the anoxic mud layer. These samples are collected from the same place in the lake and are labelled as I and II. In all cases, the sediment concentration in the jar is $0.19 \mathrm{~g} / \mathrm{l}$. Settling occurs somewhere between $G=11$ and $G=6 \mathrm{~s}^{-1}$ in anoxic mud layer II, as in the oxic layer experiments. However, in anoxic mud layer I, settling occurs already between $G=23$ and $G=11 \mathrm{~s}^{-1}$. This settling is characterized by a $75 \%$ decrease in volume concentration and a $200 \%$ increase in specific surface area of the remaining particles. The settling between 6 and $11 \mathrm{~s}^{-1}$ is characterized by an $85 \%$ decrease in volume concentration and a $600 \%$ increase in specific surface area. Settling between 23 and $11 \mathrm{~s}^{-1}$ suggests that sediments from the anoxic mud layer build up heavier flocs than sediments from the oxic layer. As the size of flocs from the oxic layer and anoxic layer are similar, this settling suggests a higher floc density for the anoxic mud layer. Figure 12 shows the measured obscuration for sediments from the anoxic mud layer. The obscuration by sediments from the anoxic mud layer ranges between 6 and $11 \%$ and is approximately three times larger than the obscuration by sediments from the oxic layer (typically 1.5 to $2.5 \%$ ). This may be caused by the larger proportion of small particles present in the anoxic layer. Obscuration increases with increasing floc sizes over the first three measurements. This is attributed to measurement errors, in particular to a too short elapsed time for heating up the laser. After this initial increase, obscuration decreases with increasing floc sizes and for the rest of the experiment.

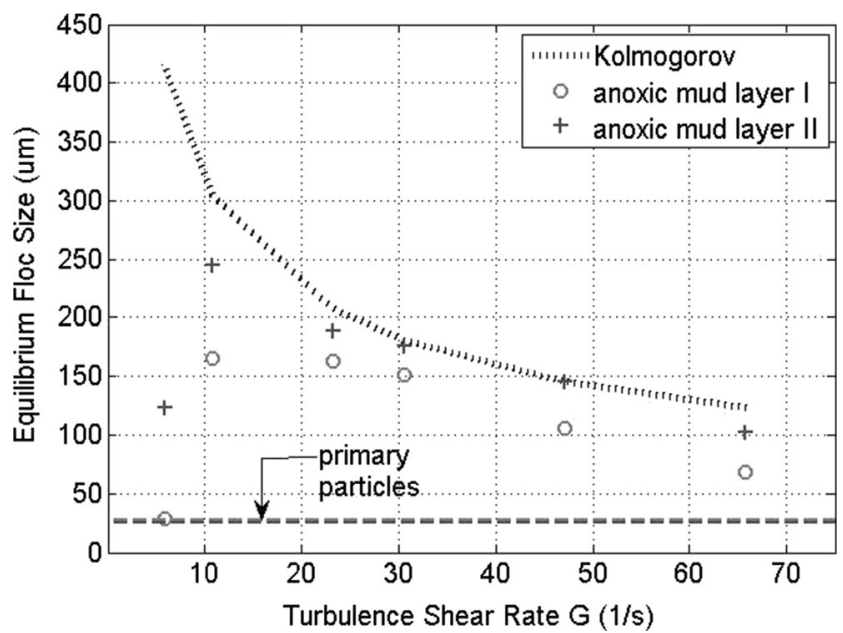

Fig. 11 Equilibrium floc size as a function of turbulence shear rate for sediments from the anoxic mud layer. The sediment concentration is $0.19 \mathrm{~g} / \mathrm{l}$ in all cases

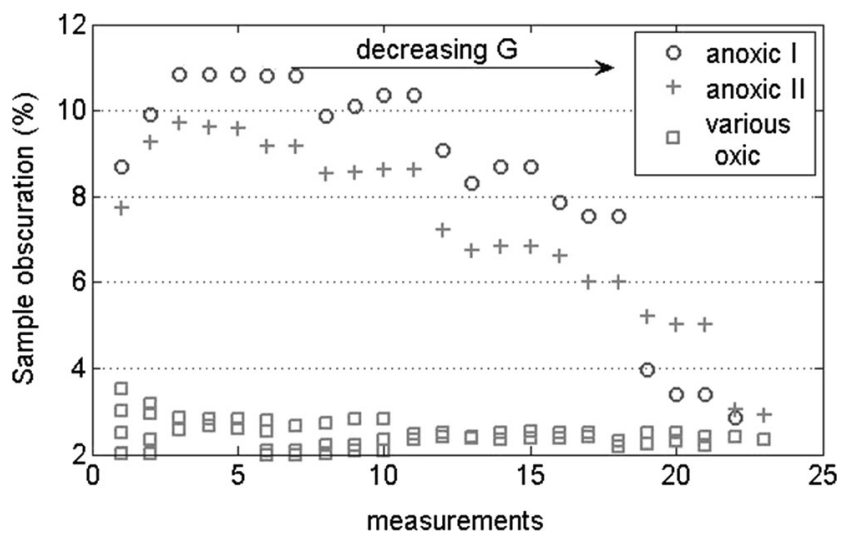

Fig. 12 Measured obscuration for sediments from the anoxic mud layer. The first measurements were carried out at the largest turbulence shear rate, whereas the last measurements were done at the smallest turbulence shear rate, with all the intermediate turbulence levels lying in between

Overall, it can be concluded that in the Markermeer sediments mobilized from the bed can flocculate, attaining an equilibrium floc size which is a function of the turbulence level. These results are in agreement with the results of Mietta et al. (2009a) and Verney et al. (2011), who also found floc sizes adjusting to the turbulence level and never exceeding the Kolmogorov micro-scale. Sediments from the oxic layer and from the anoxic mud layer attain similar equilibrium sizes at all studied $G \mathrm{~s}$, with settling occurring somewhere between $G=11$ and $G=6 \mathrm{~s}^{-1}$ in most cases. In one experiment, sediments from the anoxic layer settled somewhere between $G=$ 23 and $G=11 \mathrm{~s} \mathrm{~s}^{-1}$, which means settling at a higher turbulence level and which is attributed to a higher density of flocs from the anoxic layer. Mietta (2010) performed the same flocculation experiments but with Silica particles and found settling at every $G$ smaller than $35 \mathrm{~s}^{-1}$. Moreover, Mietta et al. (2009b) also found settling of kaolinite suspensions of $0.135 \mathrm{~g} / \mathrm{l}$ between $G=23$ and $G=11 \mathrm{~s}^{-1}$ or between $G=11$ and $G=6 \mathrm{~s}^{-1}$, depending on the electrokinetic properties of the suspension and the consequent ability of the flocs to form lighter or denser aggregates. In addition, Mietta et al. (2009a) also performed this flocculation experiment with Western Schelde mud and measured settling only between $G=6$ and $G=11 \mathrm{~s}^{-1}$. Finally, sediments from the anoxic mud layer produce a three-time larger obscuration than sediments from the oxic layer. The latter is attributed to the larger proportion in which the fine fraction is present in the anoxic layer. Moreover, for sediments suspended from the bed (oxic and anoxic), obscuration decreases as floc size increases.

\subsection{Behaviour of algae in the small-scale flocculation experiment}

To investigate the effect of algae on flocculation, the behaviour of a suspension of algae is studied first. Two species of 
Fig. 13 Left panel: several cells of Aphanizomenon just before being used in the flocculation experiment. Right panel: Aphanotece colony

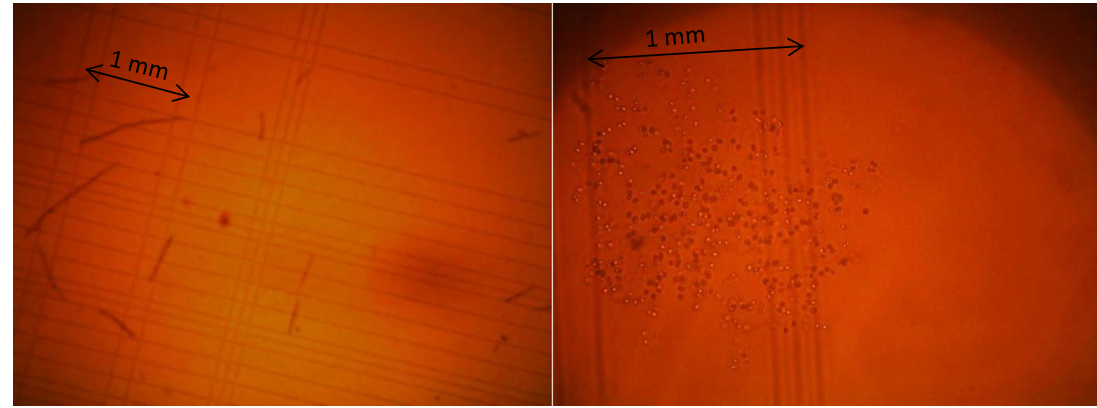

(blue-green) algae are studied: Aphanizomenon sp. and Aphanotece sp. Both species are common in the Markermeer. Aphanizomenon forms filaments consisting of a varying number of cells. Aphanotece cells are found in mucilaginous colonies of irregular shape. Figure 13 shows microscope images of the two species. Figure 14 shows the equilibrium size that Aphanotece colonies attain as a function of the turbulence level. The concentration of Aphanotece is $5 \times 10^{5}$ cells $/ \mathrm{ml}$, which is a representative of field conditions in the Markermeer. The size of Aphanotece colonies varies substantially within every measurement, but the average size is always between 250 and $300 \mu \mathrm{m}$. The colonies do not seem to grow or aggregate, and the observed average size of the colonies is not a function of the turbulence level. This is an important difference to sediments from the bed. Furthermore, Aphanotece colonies remain in suspension even at the lowest studied $G$, which is attributed to the ability of this alga to float. The obscuration caused by the Aphanotece colonies varies around $0.05 \%$, and only few measurements reach $0.1 \%$. This is one to two orders of magnitude smaller than the obscuration caused by bed sediments, indicating very different light adsorption and light diffraction properties.

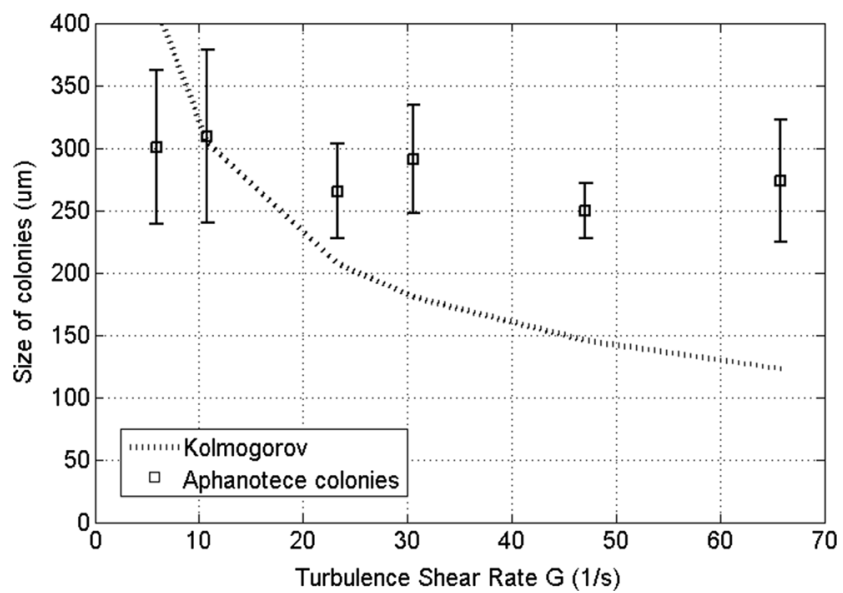

Fig. 14 Aphanotece colony size as a function of turbulence shear rate $G$, at a concentration of $5 \times 10^{5}$ cells $/ \mathrm{ml}$
Figure 15 shows the size that Aphanizomenon filamentous as a function of the turbulent shear rate in the jar. The concentration of Aphanizomenon is $5 \times$ $10^{3}$ filaments $/ \mathrm{ml}$. The latter, assuming a cell size of $10 \mu \mathrm{m}$ and an average length of filamentous of about $80 \mu \mathrm{m}$, results in a concentration of $4 \times 10^{4}$ cells $/ \mathrm{ml}$. In the Markermeer, the concentration of Aphanizomenon is $2 \times 10^{4}$ cells $/ \mathrm{ml}$. According to Fig. 15 , the equilibrium size of the filaments seems to vary between 7 and $9 \mu \mathrm{m}$ independent of shear rate. However, the largest filamentous in Fig. 13 are about $1 \mathrm{~mm}$ long. To explain this disagreement, Fig. 16 shows the evolution of $D_{50}$ during the flocculation experiment. The first sizes measured in the experiment indicated a $D_{50}$ varying between 40 and $60 \mu \mathrm{m}$, with $D_{90}$ reaching occasionally $1000 \mu \mathrm{m}$. Thus, the first measurements are in agreement with the sizes observed in Fig. 13. Apparently, the high initial turbulent shear breaks the initially large filamentous into pieces of about $10 \mu \mathrm{m}$. These pieces do not aggregate during the rest of the experiment. The obscuration by Aphanizomenon ranges between 0.3 and $0.35 \%$, much larger than for Aphanotece, owing to their smaller size (filaments are smaller than colonies).

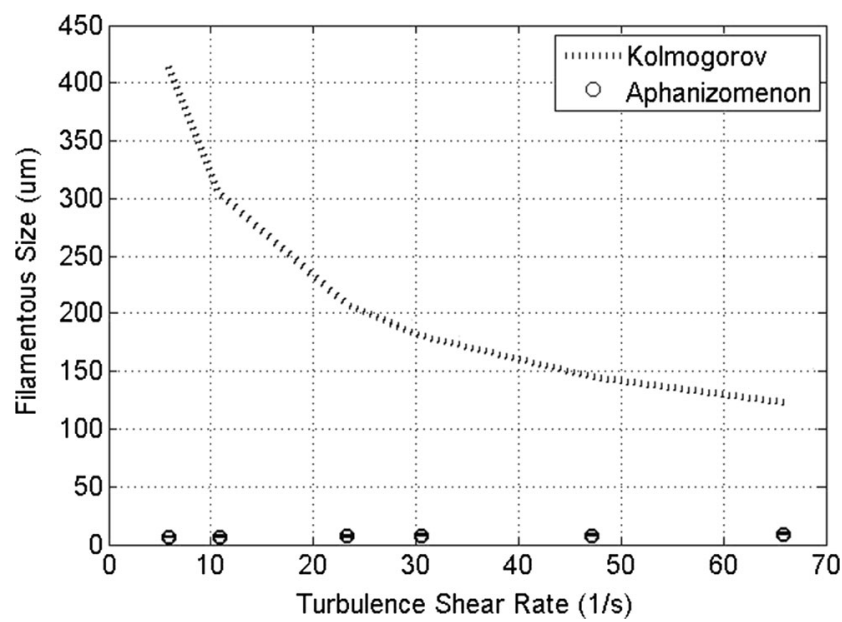

Fig. 15 Equilibrium size of Aphanizomenon filamentous as a function of turbulence shear rate and at a concentration of $1.3 \times 10^{5} \mathrm{cells} / \mathrm{ml}$ 


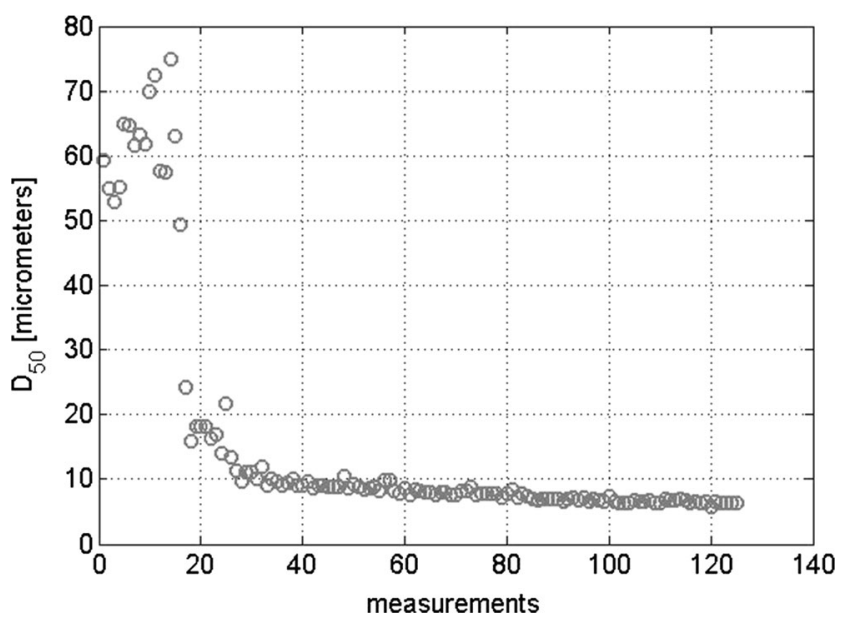

Fig. 16 Measured size of Aphanizomenon filamentous over the flocculation experiment

\subsection{Flocculation between bed sediments and algae. Effect on floc properties and light climate as a function of combined type of algae}

Figure 17 shows equilibrium floc sizes as a function of turbulent shear rate for a mixture of Aphanotece colonies and sediments from the oxic layer. This figure provides a number of important observations:

1. Settling occurs between 11 and $23 \mathrm{~s}^{-1}$. For sediments from the oxic layer (see Fig. 7), settling occurs between 6 and $11 \mathrm{~s}^{-1}$, whereas for Aphanotece colonies (see Fig. 14), no settling occurs.

2. For $G>11 \mathrm{~s}^{-1}$, the size of the biotic-abiotic aggregates in Fig. 17 is larger than the size of the flocs from the oxic layer (see Fig. 7).

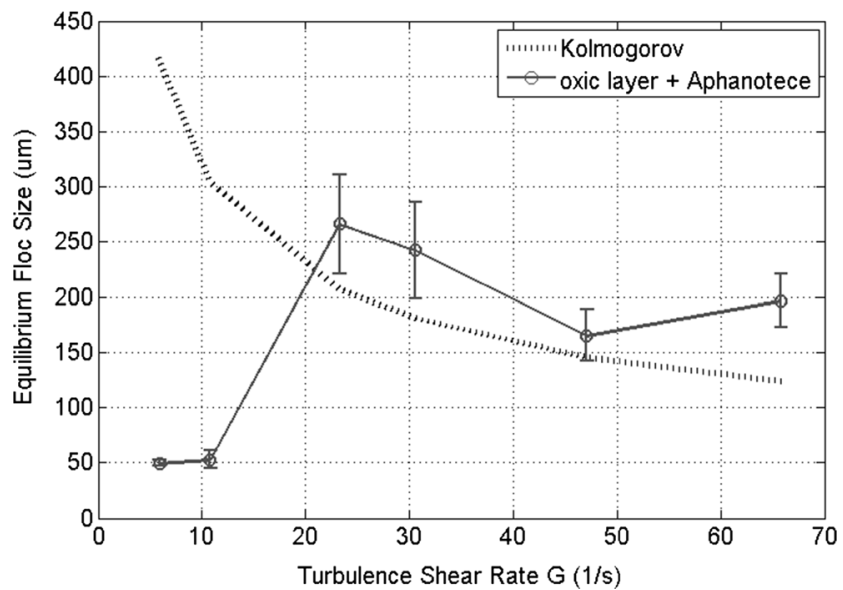

Fig. 17 Equilibrium floc size as a function of turbulence shear rate for a mixture of sediments from the oxic layer and Aphanotece colonies. The suspended sediment concentration is $0.19 \mathrm{~g} / \mathrm{l}$, and the concentration of Aphanotece is $5 \times 10^{5}$ cells $/ \mathrm{ml}$ (compare with Figs. 7 and 14)
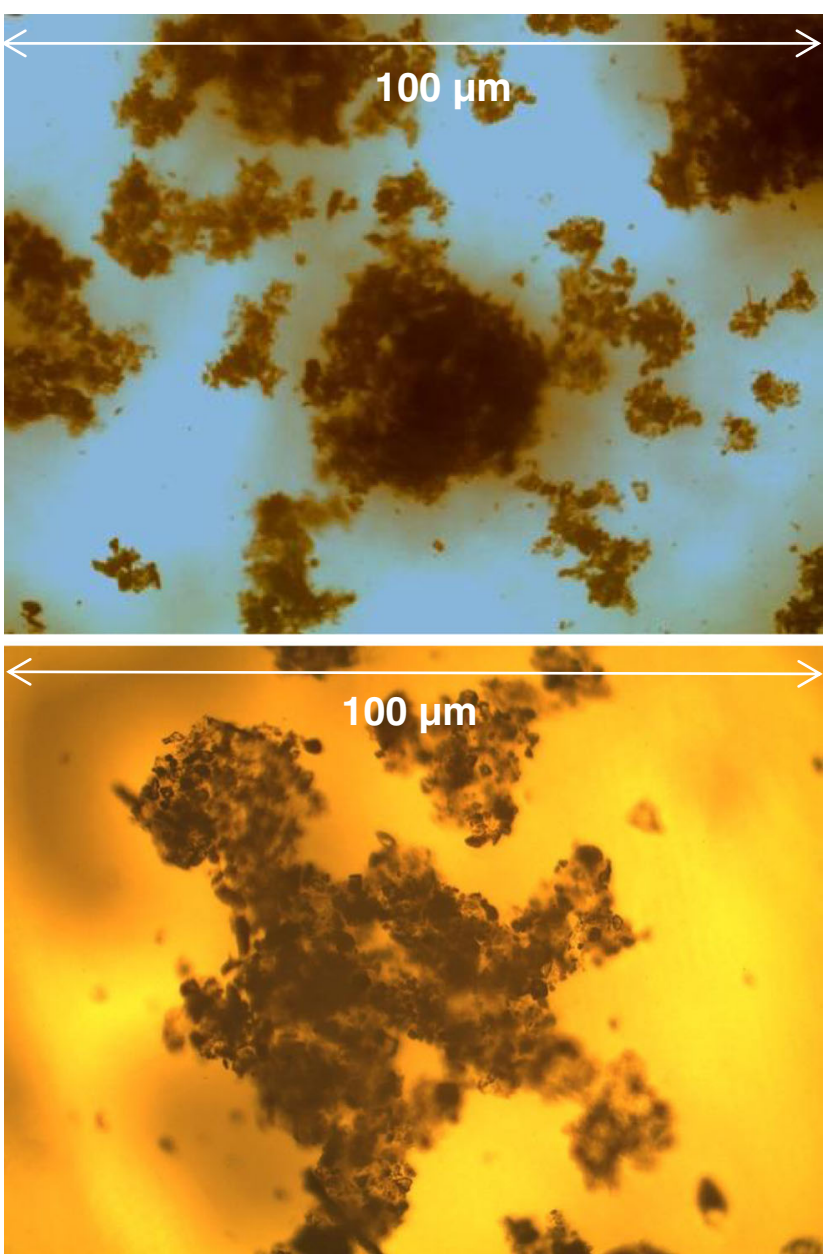

Fig. 18 Upper panel: image of a floc from the oxic layer (no algae present). Lower panel: image of a floc obtained after the flocculation experiment in which Aphanotece colonies and sediment from the oxic later are mixed

3. For $G>23 \mathrm{~s}^{-1}$, the size of the biotic-abiotic aggregates in Fig. 17 is smaller than the size of Aphanotece colonies (see Fig. 14) and follows the Kolmogorov micro-scale.

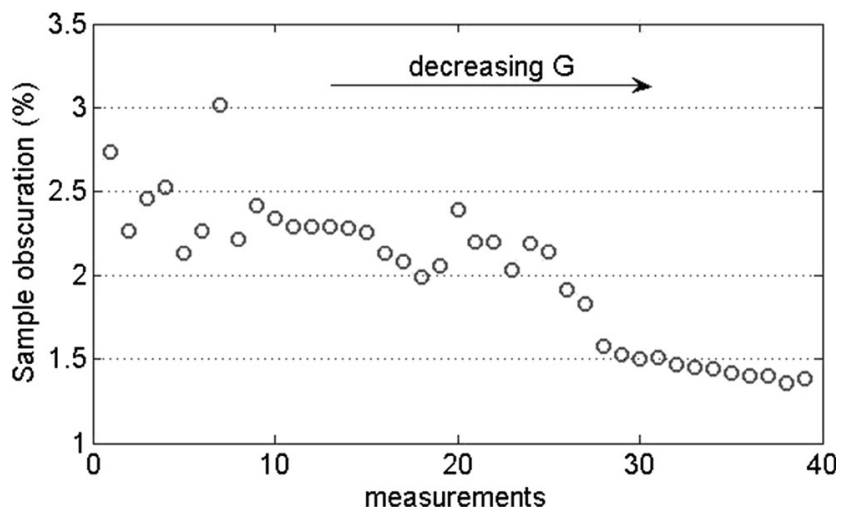

Fig. 19 Measured obscuration for a mixture of Aphanotece colonies and sediments from the oxic layer. The first measurements were performed at the largest turbulence shear rate, whereas the last measurements were done at the smallest turbulence shear rate, with all the intermediate turbulence levels in between (compare with Fig. 9) 
4. For $G<23 \mathrm{~s}^{-1}$ (after settling), the size of the particles in Fig. 17 is six to seven times smaller than the size of Aphanotece colonies (see Fig. 14).

5. For $G<23 \mathrm{~s}^{-1}$, the size of the error bars for the measurements in Fig. 17 is smaller than for Aphanotece colonies (see Fig. 14). Colonies always vary largely in size within one measurement, whereas the particles remaining in suspension in Fig. 17 do not vary in size.

These observations suggest that (almost) all Aphanotece cells are bound to the flocs, resulting in organic-inorganic aggregates. This is in agreement with the work of Verspagen et al. (2006), who reported aggregation of clay particles and algae individuals at the laboratory, as well as with other field and laboratory measurements in which biological aggregation of cohesive sediments was confirmed (Fugate and Friedrichs 2003; Van der Lee 2000a; Verney et al. 2011). The observed organic-inorganic aggregates are larger than the flocs from the oxic layer (observation 2) and smaller (but heavier) than Aphanotece colonies (observation 3 ) and settle at higher turbulence than any of the individual components (observation 1). After settling, the particles remaining in suspension are much smaller than the Aphanotece colonies (observation 4) and vary little in size (observation 5).

The aggregates resulting from this flocculation experiment were studied under the microscope upon finalization of the experiment, confirming that neither colonies of Aphanotece nor individual Aphanotece cells were found in any of the studied samples. The upper panel in Fig. 18 shows a floc from the oxic layer, whereas the lower panel in Fig. 18 shows a floc resulting from the Aphanotece and oxic layer experiment, a compound floc. The structure of the compound floc seems similar to the structure of the mineral floc. Given a similar structure, it is reasonable that larger flocs settle at a higher turbulence level (observation 1). Moreover, there does not seem to be a mainly organic region or a mainly mineral region in the combined floc, but all material seems to be mixed. The images in Fig. 18 suggest that the mechanism behind the flocculation between Aphanotece and minerals is the embedment of the algae cell-individuals into the mineral floc structure.

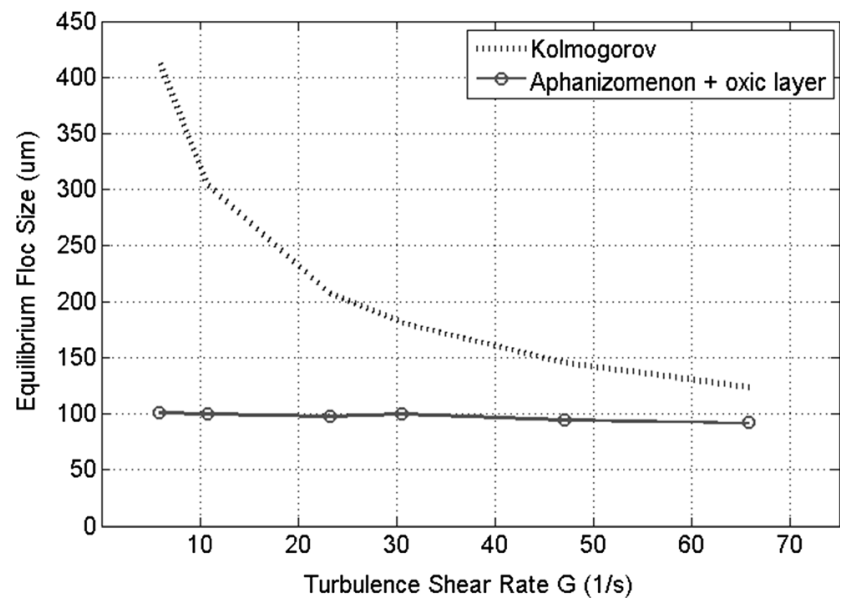

Fig. 21 Equilibrium floc size as a function of turbulence shear rate for a mixture of sediments from the oxic layer and Aphanizomenon filamentous. The suspended sediment concentration is $0.19 \mathrm{~g} / \mathrm{l}$, and the initial concentration of Aphanizomenon is $5 \times 10^{3}$ filamentous $/ \mathrm{ml}$ (compare with Figs. 7 and 17)

This embedment is likely to be promoted by polysaccharides excreted by the algae.

Until settling, the average equilibrium size of the combined flocs follows but exceeds the Kolmogorov micro-scale, probably because of the polysaccharides providing a stronger bond between the individual particles in the aggregate and therefore increasing the yield stress of the floc. This is in agreement with other results reported in literature, in which very large aggregates in presence of algae are described (Fugate and Friedrichs 2003; Lunau et al. 2006; Van der Lee 2000a). Settling is characterized by a decrease of $75 \%$ in the volume concentration and an increase of $270 \%$ in specific surface area. Figure 19 shows the obscuration of a mixture of sediments from the oxic layer and Aphanotece colonies. This obscuration is in the same range as for the sediments from the oxic layer. However, the obscuration caused by the particles remaining after settling ( $25 \%$ in volume) is around $1.5 \%$; whereas for sediments from the oxic layer, this is less than $0.5 \%$. The latter implies that a larger amount of inorganic fines remain in suspension after settling of the organicinorganic aggregates. Presumably, some fines cannot
Fig. 20 Summary of flocculation process between sediment from the oxic layer and Aphanotece colonies. All Aphanotece cells are bounded to the flocs, which have a similar structure to the inorganic flocs. Flocs grow as $G$ decreases, until settling occurs. Only bed sediments are left behind in the water column

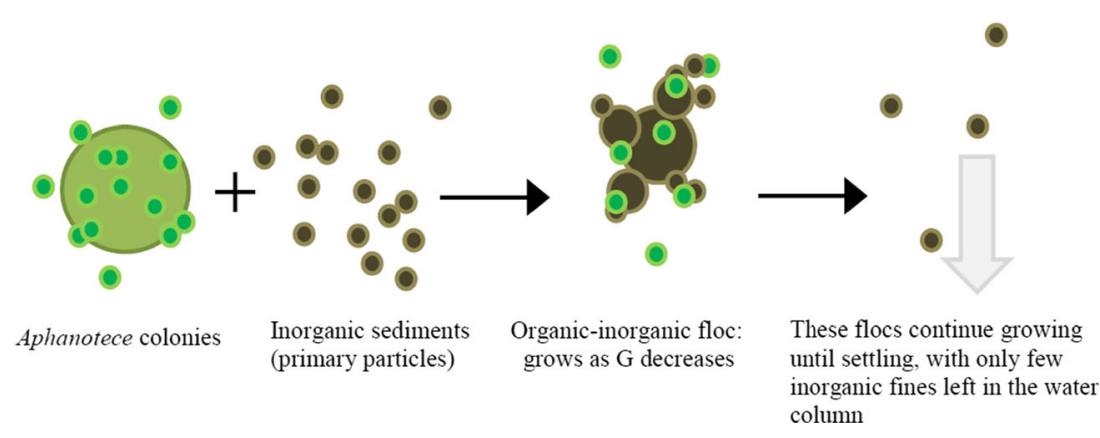

column 


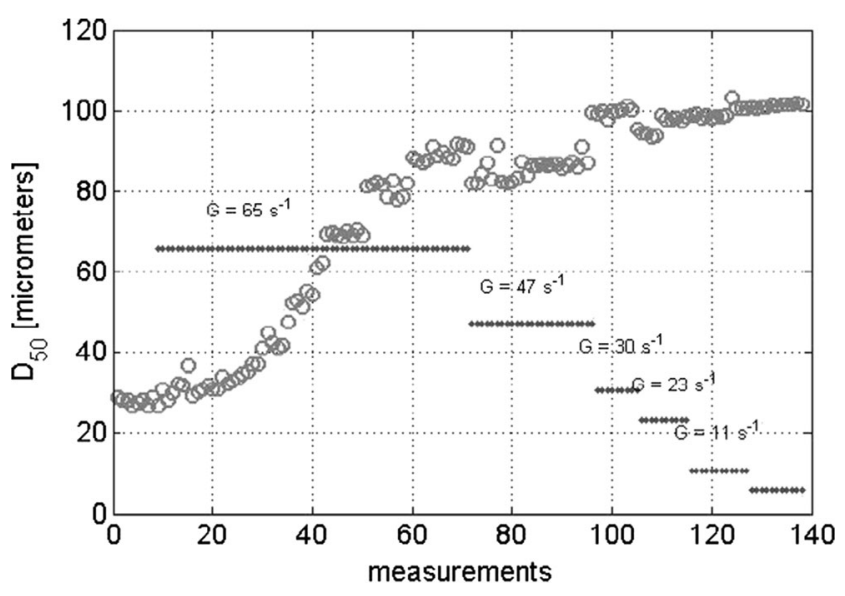

Fig. 22 Evolution of the measured $D_{50}$ during the flocculation experiment for a mixture of sediments from the oxic layer and Aphanizomenon filamentous. The suspended sediment concentration is $0.19 \mathrm{~g} / \mathrm{l}$, and the concentration of Aphanizomenon is $5 \times 10^{3}$ filaments $/ \mathrm{ml}$

flocculate with the large flocs because of the presence of the algae cells and are therefore left behind after settling.

Figure 20 shows an illustration summarizing the flocculation process between sediments from the oxic layer and Aphanotece colonies. Flocculation between Aphanotece colonies and sediments from the oxic layer results in all Aphanotece cells bounded to the flocs, with a structure similar to an inorganic floc. Flocs grow as $G$ decreases, until settling occurs. After settling, only bed sediments are left behind in the water column.

Next, the results of the flocculation experiments between sediments from the oxic layer and Aphanizomenon filamentous are shown. A concentration of $5 \times$

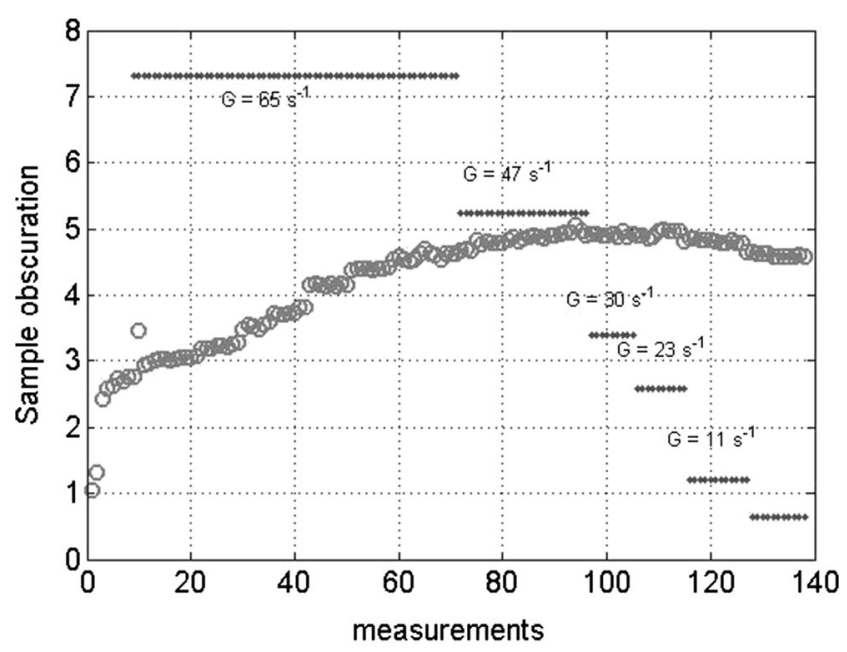

Fig. 23 Measured obscuration for a mixture of Aphanizomenon filamentous and sediments from the oxic layer. The first measurements were performed at the largest turbulence shear rate, whereas the last measurements were done at the smallest turbulence shear rate, with all the intermediate turbulence levels in between (compare with Figs. 10 and 19)
$10^{3}$ filaments $/ \mathrm{ml}$ is used. After the experiment, counting of Aphanizomenon filamentous revealed that their concentration dropped to $3.9 \times 10^{3}$ filaments $/ \mathrm{ml}$. It is assumed that the remaining $1.1 \times 10^{3}$ filaments $/ \mathrm{ml}$ became part of the organic-inorganic aggregates during the flocculation experiment. Note that break-up of filaments was not observed when accompanied by mud in the water column. Figure 21 shows equilibrium floc size as a function of turbulent shear rate for a mixture of sediments from the oxic layer and Aphanizomenon filamentous. Figure 22 shows the evolution of the measured $D_{50}$ over the complete flocculation experiment, with $G$ at every measurement. The first measurements show a $D_{50}$ of suspended particles of about $30 \mu \mathrm{m}$, and after which, $D_{50}$ increases with time until reaching an equilibrium floc size of about $90 \mu \mathrm{m}$ for $G=65 \mathrm{~s}^{-1}$. Afterwards, the floc sizes only increase by $10 \mu \mathrm{m}$ over the rest of the experiment. This is a much smaller increase than in any of the other studied cases.

At the beginning of the experiment, only primary particles are present $(30 \mu \mathrm{m})$, and the concentration of these particles, assuming a density between $1.1 \times 10^{3}$ and $1.2 \times$ $10^{3} \mathrm{~kg} / \mathrm{m}^{3}$ (Droppo et al. 2000), is of about $11.5 \times 10^{3}$ to $12.5 \times 10^{3}$ particles $/ \mathrm{ml}$. This is 2.5 times larger than the initial concentration of Aphanizomenon filaments. After flocculation, a floc size of about $90 \mu \mathrm{m}$ is attained, and thus, the concentration of mineral flocs, given a constant density of flocs of $1.1 \times 10^{3}$ to $1.2 \times 10^{3} \mathrm{~kg} / \mathrm{m}^{3}$, becomes $0.5 \times 10^{3} \mathrm{floc} /$ $\mathrm{ml}$, which is eight times smaller than the concentration of algae filaments at the end of the experiment. At this point, further flocculation does not seem to occur. The latter is because the drop in Aphanizomenon concentration during the experiment is believed to be caused by flocculation with inorganic fines, and thus, $1.1 \times 10^{3}$ filaments $/ \mathrm{ml}$ of Aphanizomenon belong now to the $0.5 \times 10^{3} \mathrm{floc} / \mathrm{ml}$ existing in the suspension (i.e. two algae filaments per floc) and so do the polysaccharides excreted by the algae. Therefore, it is presumed that steric repulsion happens between the organic-inorganic flocs (i.e. including its polysaccharides) and the remaining suspended filamentous, preventing further flocculation during the rest of the experiment (Hiemenz and Rajagopalan 1997).

Figure 23 shows the obscuration caused by a mixture of sediments from the oxic layer and Aphanizomenon filamentous. Obscuration increases from 2.5 to $5 \%$ while $D_{50}$ increases from 30 to $100 \mu \mathrm{m}$ (at $G=65 \mathrm{~s}^{-1}$ ). After $100 \mu \mathrm{m}$ is reached, obscuration decreases by $0.5 \%$. The increase in obscuration for increasing sizes is remarkable, since sediments from the oxic layer produce smaller obscuration for increasing sizes (see Fig. 9). The fact that flocs absorb and/or scatter light in a different way suggests that they have a different structure. It is possible that this difference in structure is created by the aggregation of filamentous. 


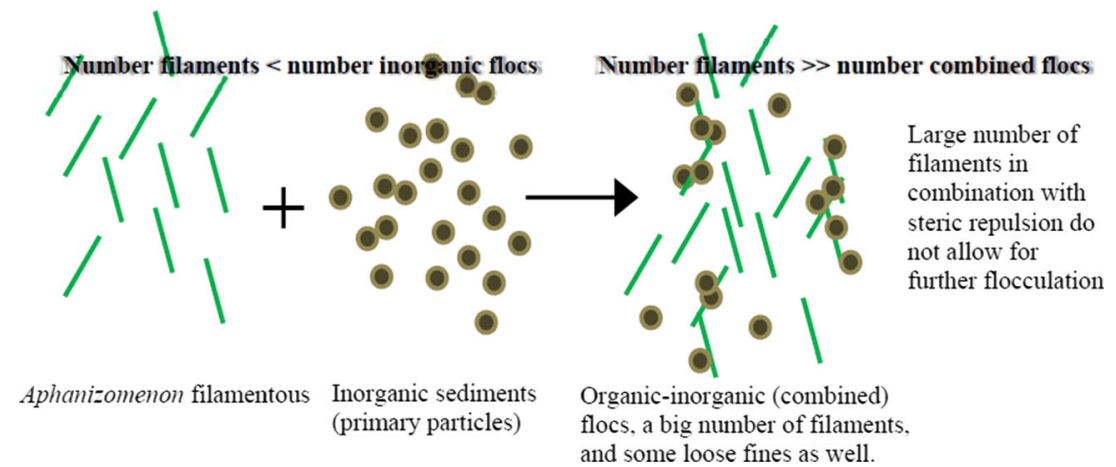

Fig. 24 Summary of the flocculation process between Aphanizomenon filamentous and sediments from the oxic layer. Flocculation occurs initially between the sediments from the oxic layer and the filaments.

After a certain floc size is attained, the larger amount of filaments relative to the number of flocs and steric repulsion do not allow for further flocculation

Figure 24 shows an illustration summarizing the flocculation process between Aphanizomenon filamentous and mineral flocs from the oxic layer. Flocculation occurs initially between the sediments from the oxic layer and the filaments. After a certain size is attained, the number of filaments largely exceeds the number of flocs, and steric repulsion does not allow for further flocculation between filaments and floc. This results in a turbid suspension with a large number of small particles.

Summarizing, sediments mobilized from the bed and water column algae can flocculate. This flocculation affects the properties of the original flocs, as well as the light climate in the water column. This effect of mutual flocculation with algae on the floc properties was also suggested by Sanford et al. (2001), Fugate and Friedrichs (2003) and Mikkelsen (2002). Moreover, the properties of these compound flocs depend strongly upon the type of algae. When combined with Aphanotece colonies, suspended sediments attain larger equilibrium sizes and settle earlier. On the other hand, when combined with Aphanizomenon filamentuos, flocculation is limited by steric repulsion and abundance of filaments, resulting in smaller floc sizes. Furthermore, a different floc structure is suggested, which increases the light attenuation for increasing

floc sizes. Finally, it has been demonstrated that flocculation with diatoms may also affect the light climate, as in the case of Aphanizomenon, where flocculation with bed sediments doubles the obscuration.

\subsection{Measurements of the flocculation rate}

Figure 25 shows flocculation rates for sediments from the oxic layer and from the anoxic muddy layer, at $0.19 \mathrm{~g} / \mathrm{l}$ concentration. The $\mathrm{x}$-axis represents the turbulent shear rate $G$ at which flocculation is measured. The $\mathrm{y}$-axis represents the flocculation rate, which is defined as $\Delta D_{50} / D_{0} \Delta t$, where $D_{0}$ is the size of the flocs at the beginning of each $G$. Table 3 indicates these initial floc sizes. Flocculation rates measured at $G=65 \mathrm{~s}^{-1}$ are one order of magnitude larger than the rest of the flocculation rates. This is expected, since the flocculation rate is very high when the floc size is close to the size of the primary particles (Mietta 2010). During the first phase of the flocculation process, aggregation dominates, and the largest flocs at the given conditions are formed. Later, break-up becomes more important preventing the largest flocs from continuing to grow, while further

Fig. 25 Flocculation rate as a function of $G$, for sediments from the oxic layer and for sediments from the anoxic muddy layer

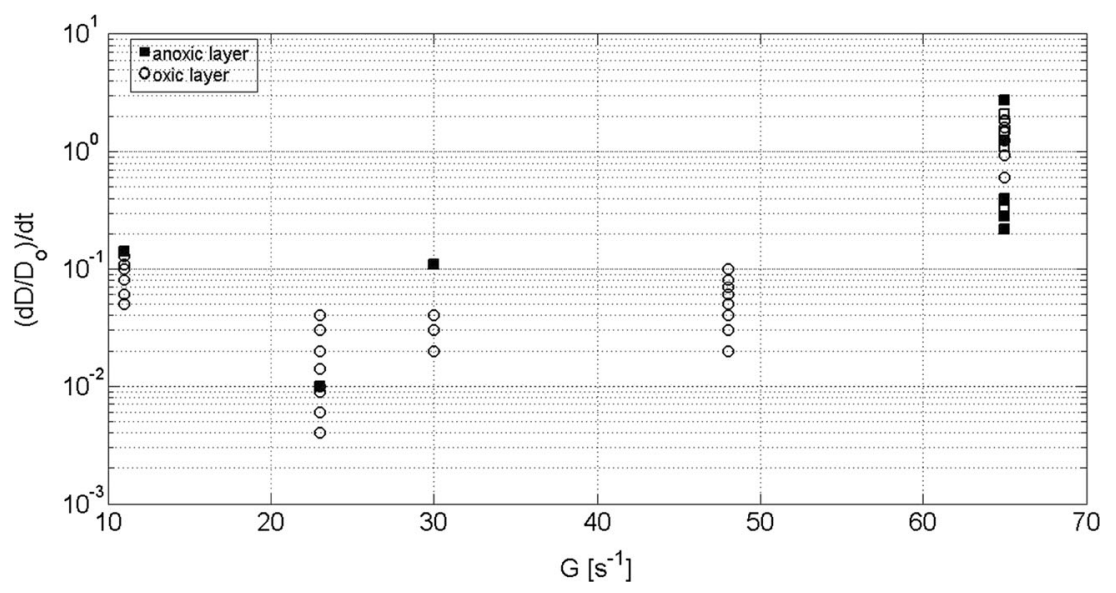


Table 3 Initial floc sizes for each of the studied $G$ s

\begin{tabular}{|c|c|c|c|c|c|c|}
\hline Order & $\begin{array}{l}G=65 \mathrm{~s}^{-1} \\
\text { First }\end{array}$ & $\begin{array}{l}G=47 \mathrm{~s}^{-1} \\
\text { Second }\end{array}$ & $\begin{array}{l}G=30 \mathrm{~s}^{-1} \\
\text { Third }\end{array}$ & $\begin{array}{l}G=23 \mathrm{~s}^{-1} \\
\text { Fourth }\end{array}$ & $\begin{array}{l}G=11 \mathrm{~s}^{-1} \\
\text { Fifth }\end{array}$ & $\begin{array}{l}G=6 \mathrm{~s}^{-1} \\
\text { Sixth }\end{array}$ \\
\hline $\begin{array}{l}\text { Initial size } \\
\text { of flocs }\end{array}$ & $\begin{array}{l}\text { Primary } \\
\text { particles }\end{array}$ & $\begin{array}{l}\text { Equilibrium floc } \\
\text { size from } G=65 \mathrm{~s}^{-1}\end{array}$ & $\begin{array}{l}\text { Equilibrium floc } \\
\text { size from } G=47 \mathrm{~s}^{-1}\end{array}$ & $\begin{array}{l}\text { Equilibrium floc } \\
\text { size from } G=30 \mathrm{~s}^{-1}\end{array}$ & $\begin{array}{l}\text { Equilibrium floc } \\
\text { size from } G=23 \mathrm{~s}^{-1}\end{array}$ & $\begin{array}{l}\text { Equilibrium floc } \\
\quad \text { size from } G=11 \mathrm{~s}^{-1}\end{array}$ \\
\hline
\end{tabular}

aggregation yields an increase in the size of the smallest flocs (Mietta 2010). The flocculation rate in this last part of the process is small (Winterwerp 2002; Winterwerp 1998). The flocculation rate appears to decrease with $G$ until $G=23 \mathrm{~s}^{-1}$, beyond which an increase in flocculation rate is measured. This is because settling occurs between $G=23$ and $G=11 \mathrm{~s}^{-1}$, leading to a different composition of the suspension with a decreased number of particles and with relatively more fines and therefore to a faster flocculation rate. Before settling, the flocculation rate can be approximately predicted as:

$$
\begin{gathered}
\frac{d D}{d t}=\frac{D-D_{0}}{T_{f}} \\
\frac{d D / D_{0}}{d t}=\frac{\left(D-D_{0}\right) / D_{0}}{T_{f}} \\
\text { if } D \gg D_{0}, T_{f}=k_{A} c G D_{0} \text { (Winterwerp 1998). Thus, }
\end{gathered}
$$

$$
\begin{aligned}
& \frac{d D / D_{0}}{d t}=\left(D-D_{0}\right) k_{\mathrm{A}} c G \\
& \frac{\left.\frac{d D / D_{0}}{d t}\right|_{G=G_{1}}}{\left.\frac{d D / D_{0}}{d t}\right|_{G=G_{2}}}=\frac{\left(D_{1}-D_{0}\right) G_{1}}{\left(D_{2}-D_{0}\right) G_{2}}
\end{aligned}
$$

Fig. 26 Flocculation rate as a function of $G$, for a mixture of sediments from the oxic layer and Aphanotece colonies. Sediment concentration is $0.19 \mathrm{~g} / 1$, and concentration of Aphanotece is $5 \times 10^{5}$ cells $/ \mathrm{ml}$
Where:

$D \quad$ size of the flocs

$D_{0} \quad$ size of the primary particles

$k_{\mathrm{A}} \quad$ aggregation coefficient $\left(\mathrm{kg} / \mathrm{m}^{2}\right)$, and

$c \quad$ sediment concentration $\left(\mathrm{kg} / \mathrm{m}^{3}\right)$

For example, one of the measured flocculation rates at $G=$ $47 \mathrm{~s}^{-1}$ is of about $0.05 \mathrm{~h}^{-1}$; which, given the initial floc size at $G=47 \mathrm{~s}^{-1}, 137 \mu \mathrm{m}$, and the final floc size at $G=33 \mathrm{~s}^{-1}$, $150 \mu \mathrm{m}$, results in a prediction of a flocculation rate of $0.03 \mathrm{~h}^{-1}$, which is in the measured range.

Figure 26 shows flocculation rates for a mixture of sediments from the oxic layer and Aphanotece colonies, as a function of $G$. The concentration of sediments from the oxic layer is $0.19 \mathrm{~g} / \mathrm{l}$, and the concentration of Aphanotece is $5 \times$ $10^{5}$ cells $/ \mathrm{ml}$. A mixture of sediments from the oxic layer and Aphanotece colonies yields a flocculation rate larger than the flocculation rate of sediments from the oxic layer. Unfortunately, the flocculation rate of this mixture is measured for $G=$ $23 \mathrm{~s}^{-1}$ only. Literature also provides examples of increased flocculation rates because of aggregation with algae, in particular those of Verney et al. (2009) and van Leussen (1994).

Figure 27 shows flocculation rates for a mixture of sediments from the oxic layer and Aphanizomenon filamentous, as a function of $G$. The concentration of sediments from the oxic layer is $0.19 \mathrm{~g} / \mathrm{l}$, and the concentration of Aphanizomenon is $5 \times 10^{3}$ filaments $/ \mathrm{ml}$. The measured flocculation rates are in the range of those measured for bed sediments only but a bit larger. This is expected, since the organic-inorganic flocs that Aphanizomenon form consist mostly of mineral material $(1 \times$

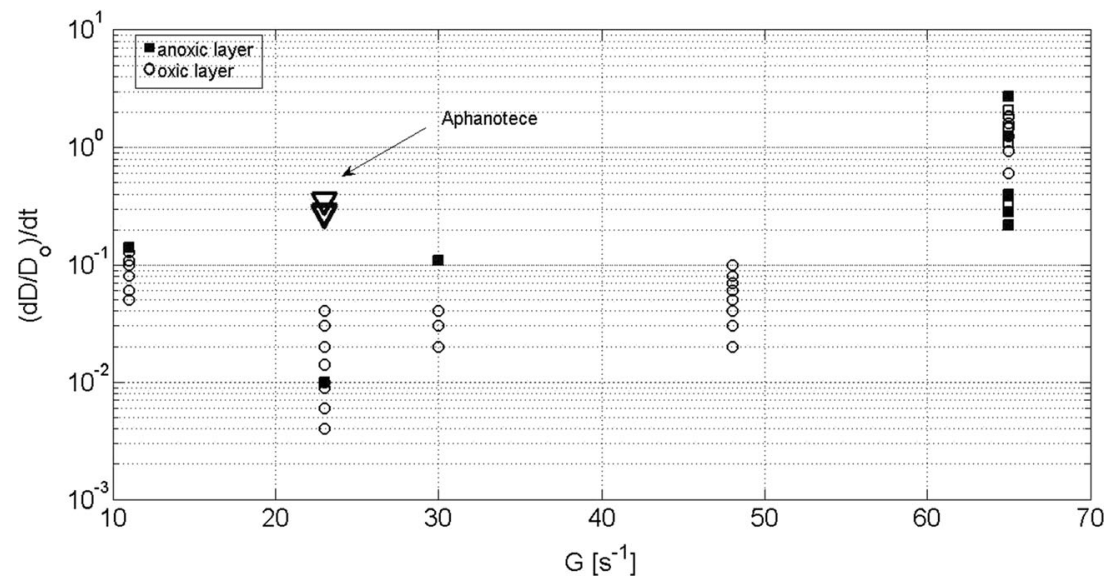


Fig. 27 Flocculation rate as a function of $G$, for a mixture of sediments from the oxic layer and Aphanizomenon filamentous.

Sediment concentration is $0.19 \mathrm{~g} /$ 1 , and the concentration of Aphanizomenon is $5 \times$

$10^{3}$ individuals $/ \mathrm{ml}$

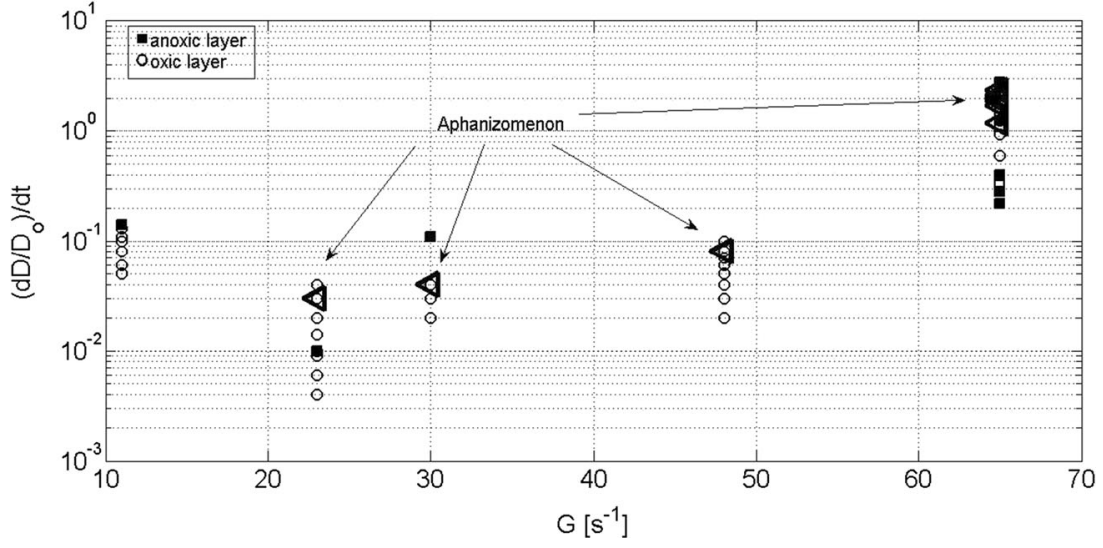

$10^{6}$ filaments in $0.5 \times 10^{6}$ flocs), and thus, they are formed at a similar rate as mineral flocs until algae filaments are added to the floc and steric repulsion occurs.

\section{Conclusions}

The loose bed sediments in the Markermeer form an anoxic layer with a mean thickness of about $10 \mathrm{~cm}$, with a considerable variation in thickness though. On top of this anoxic layer, an oxic layer few millimetres thick is formed. When mobilized from the bed and suspended in the water column, these sediments can flocculate, with equilibrium floc sizes following the Kolmogorov micro-scale. However, in practice, a limited residence time in the water column may result in settling of the flocs prior to attaining an equilibrium size. Flocs consisting of sediments from the oxic layer are less dense than flocs of sediments from the anoxic mud layer and induce a threetime smaller obscuration. The latter is attributed to the larger proportion of fines in the anoxic layer. Therefore, erosion of the anoxic layer will induce a higher turbidity in the water column. This is in agreement with observations of higher turbidity after storms, when the anoxic layer is brought into suspension, and turbidity levels increase disproportionally beyond the background turbidity in the lake, induced by the frequent re-suspension of the oxic layer.

Colonial algae group to form colonies, but their size appears not to be influenced by the turbulence field in the water column. Moreover, the size of these colonies varies substantially over the measurements. On the other hand, filamentous algae do not aggregate mutually but break up as a result of intense turbulent agitation. It is hypothesized that this breakup does not occur when accompanied by fines in the water column. Nevertheless, the stresses at which this break-up would happen do not occur in the field. Both algae species produce, at their field concentrations, an obscuration much smaller than the obscuration caused by suspended bed sediments at its field concentration.
Together in the water column, sediment mobilized from the bed and algae can flocculate, resulting in the formation of biotic-abiotic aggregates. The characteristics of these aggregates are a function of the type of algae and the environmental conditions. Moreover, the dynamics of flocculation and the impact of flocculation on the environment (e.g. turbidity) may vary as a function of the type of algae as well. In the case of the colonial algae, the biotic-abiotic aggregates are larger than those consisting of inorganic sediments only, possibly because of the increase in floc strength by polysaccharides produced by the algae. Furthermore, we presume that these polysaccharides are also responsible for the larger flocculation rate. In the case of filamentous algae, biotic-abiotic flocs consist mainly of fines and few (one to three) filaments. Flocs grow at the rate at which inorganic flocs grow, until a certain size. Then, flocculation stops because of the large amount of filaments around the flocs (the concentration of filaments is eight times larger than the concentration of flocs) and because of steric repulsion between filaments and flocs. Note that steric repulsion is caused by the presence of few filaments in every floc. Additionally, the obscuration by flocs composed of oxic layer sediments and filaments is twice the obscuration by sediments from the oxic layer alone. This is partly explained by steric repulsion which prevents filaments and organic-inorganic flocs to further flocculate, leaving a large number of small particles in the water column. Moreover, it appears that mutual flocculation between filaments and bed sediments also increases the obscuration of the suspension.

The present understanding of the fine sediment dynamics in the Markermeer predicts that the light climate in the lake is a function of fines re-suspended from the bed. However, the results presented here also suggest that the interaction/ flocculation of bed sediments with various types of bluegreen algae in the lake plays an important role. A more detailed study of diatom characteristics and their distribution in the Markermeer is required to fully understand the light climate and turbidity patterns in the lake. Furthermore, the settling of all Aphanotece colonies from the water column has important 
implications for the ecology of the lake, withdrawing a relevant amount of nutrients from the food chain of the lake. Note that without the presence of suspended bed sediments, settling of Aphanotece colonies does not occur at any of the studied turbulence fields, and thus, colonies would always be available to be eaten by the zooplankton. Finally, we also presume that the aggregation of algae with fines constitutes an obstacle for the feeding of mussels and other filter feeders in the lake. The latter is because when aggregated to fines, algae belongs to a much larger and more consistent structure than when isolated from fines, causing a decrease in the efficiency with which filter feeders process the aggregates and feed from the algae.

\section{References}

Bainbridge ZT, Wolanski E, Álvarez-Romero JG, Lewis SE, Brodie JE (2012) Fine sediment and nutrient dynamics related to particle size and floc formation in a Burdekin River flood plume, Australia. Mar Pollut Bull 65(4-9):236-248

Bale AJ, Morris AW (1987) In situ measurement of particle size in estuarine waters. Estuar Coast Shelf Sci 24(2):253-263

Berlamont J, Ockenden M, Toorman E, Winterwerp J (1993) The characterisation of cohesive sediment properties. Coast Eng 21(1):105-128

Bouyer D, Coufort C, Liné A, Do-Quang Z (2005) Experimental analysis of floc size distributions in a $1-\mathrm{L}$ jar under different hydrodynamics and physicochemical conditions. J Colloid Interface Sci 292(2): 413-428

de Lucas Pardo MA, Bakker M, van Kessel T, Cozzoli F, Winterwerp JC (2013) Erodibility of soft freshwater sediments in Markermeer: the role of bioturbation by meiobenthic fauna. Ocean Dyn 63(9-10): $1137-1150$

Droppo I, Walling D, Ongley E (2000) Influence of floc size, density and porosity on sediment and contaminant transport. IAHS Publ Int Assoc Hydrol Sci 263:141-147

Dyer K, Manning A (1999) Observation of the size, settling velocity and effective density of flocs, and their fractal dimensions. J Sea Res 41(1):87-95

Fettweis M, Francken F, Pison V, Van den Eynde D (2006) Suspended particulate matter dynamics and aggregate sizes in a high turbidity area. Mar Geol 235(1):63-74

Fugate DC, Friedrichs CT (2003) Controls on suspended aggregate size in partially mixed estuaries. Estuar Coast Shelf Sci 58(2):389-404

Guide O (1998) Malvern Mastersizer 2000. Malvern Instruments Ltd., Worchestershire

Hiemenz PC, Rajagopalan R (1997) Principles of colloid and surface chemistry, revised and expanded. New York, CRC Press

KIWA (1976) Bekerglasproef voor coagulatie. 1. Mengtijden en g-waarden

Lartiges BS et al (2001) Composition, structure and size distribution of suspended particulates from the Rhine River. Water Res 35(3):808816

Lee BJ, Toorman E, Molz FJ, Wang J (2011) A two-class population balance equation yielding bimodal flocculation of marine or estuarine sediments. Water Res 45(5):2131-2145

Lunau M, Lemke A, Dellwig O, Simon M (2006) Physical and biogeochemical controls of microaggregate dynamics in a tidally affected coastal ecosystem. Limnol Oceanogr 51(2):847

Manning AJ, Baugh JV, Spearman JR, Whitehouse RJ (2010) Flocculation settling characteristics of mud: sand mixtures. Ocean Dyn 60(2):237-253
McCabe JC (1991) Observations of estuarine turbulence and floc size variations. Thesis, Polytechnic South West Institute of Marine Studies, Plymouth in collaboration with Plymouth Marine Laboratory, Plymouth

Mehta A et al (2009) Resuspension dynamics in Lake Apopka, Florida. Final synopsis report, submitted to St. Johns River Water Management District, Palatka, Florida, June 2009, Report No. UFL/COEL-2009/00, p 158

Mietta F (2010) Evolution of the floc size distribution of cohesive sediments. Delft University of Technology, TU Delft

Mietta F, Chassagne C, Manning AJ, Winterwerp JC (2009a) Influence of shear rate, organic matter content, $\mathrm{pH}$ and salinity on mud flocculation. Ocean Dyn 59(5):751-763

Mietta F, Chassagne C, Winterwerp J (2009b) Shear-induced flocculation of a suspension of kaolinite as function of $\mathrm{pH}$ and salt concentration. J Colloid Interface Sci 336(1):134-141

Mikkelsen OA (2002) Examples of spatial and temporal variations of some fine-grained suspended particle characteristics in two Danish coastal water bodies. Oceanol Acta 25(1):39-49

Mikkelsen O, Pejrup M (1998) Comparison of flocculated and dispersed suspended sediment in the Dollard estuary. Geol Soc Lond, Spec Publ 139(1):199-209

Mikkelsen OA, Pejrup M (2000) In situ particle size spectra and density of particle aggregates in a dredging plume. Mar Geol 170(3-4):443-459

Nagata S (1975) Mixing: principles and applications. Kodansha, Tokyo, Chap. 6

Noordhuis R, Houwing E (2003) Afname van de driehoeksmossel in het markermeer. RIZA report

Sanford LP, Suttles SE, Halka JP (2001) Reconsidering the physics of the Chesapeake Bay estuarine turbidity maximum. Estuaries 24(5):655-669

Sperazza M, Moore JN, Hendrix MS (2004) High-resolution particle size analysis of naturally occurring very fine-grained sediment through laser diffractometry: research methods papers. J Sediment Res 74(5):736-743

Van der Lee W (2000a) Parameters affecting mud floc size on a seasonal time scale: the impact of a phytoplankton bloom in the Dollard estuary, The Netherlands. Proc Mar Sci 3:403-421

van der Lee WTB (2000b) Temporal variation of floc size and settling velocity in the Dollard estuary. Cont Shelf Res 20:1495-1511

van Duin EHS (1992) Sediment transport, light and algal growth in the Markermeer. Ph.D. Thesis, Agricultural University, Wageningen

Van Eerden M, van Rijn S (2003) Redistribution of the Cormorant population in the IJsselmeer area. Cormorant Res Group Bull 5:33-37

Van Kessel T, Boer GD, Boderie P (2008) Calibration suspended sediment model Markermeer. Deltares, report Q, 4612

Van Leussen W (1994) Estuarine macroflocs - their role in finegrained sediment transport. PhD-thesis, Utrecht University, The Netherlands

Vdović N, Obhođaš J, Pikelj K (2010) Revisiting the particle-size distribution of soils: comparison of different methods and sample pretreatments. Eur J Soil Sci 61(6):854-864

Verney R, Lafite R, Brun-Cottan J-C (2009) Flocculation potential of estuarine particles: the importance of environmental factors and of the spatial and seasonal variability of suspended particulate matter. Estuar Coasts 32(4):678-693

Verney R, Lafite R, Claude Brun-Cottan J, Le Hir P (2011) Behaviour of a floc population during a tidal cycle: laboratory experiments and numerical modelling. Cont Shelf Res 31(10):S64-S83

Verspagen JM, Visser PM, Huisman J (2006) Aggregation with clay causes sedimentation of the buoyant cyanobacteria Microcystis spp. Aquat Microb Ecol 44(2):165-174

Vijverberg T, Winterwerp J, Aarninkhof S, Drost H (2011) Fine sediment dynamics in a shallow lake and implication for design of hydraulic works. Ocean Dyn 61(2-3):187-202

Winterwerp JC (1998) A simple model for turbulence induced flocculation of cohesive sediment. J Hydraul Res 36(3):309-326

Winterwerp J (2002) On the flocculation and settling velocity of estuarine mud. Cont Shelf Res 22(9):1339-1360 